\title{
Stratigraphic ranges of selected miospores in coal seams of Upper Coal Measures age in Oxfordshire and S.E. Warwickshire
}

\author{
A. H. V. SMITH \\ National Coal Board, Yorkshire Regional Laboratory, Golden Smithies Lane, Wath-upon-Dearne, Rotherham, Yorkshire S63 \\ $7 \mathrm{EW}$
}

\begin{abstract}
The extensive programme of boring recently undertaken by the National Coal Board to establish the limits of the concealed coalfield in Oxfordshire and southeast Warwickshire, has provided a unique sequence of high volatile bituminous coals from the upper part of the Upper Coal Measures suitable for spore analysis. The coals are mainly bright and the possible implications for the spore flora are briefly considered. The spores from the coals are characteristic of Westphalian D assemblages but the problem of recognising the base of the Westphalian $D$ is discussed. It is concluded that the seams under investigation are all of Westphalian D age. Two new species, Vestispora burfordiensis and $V$. witneyensis are described. The occurrence of these species as well as Schopfites dimorphus and Punctatosporites granifer in Oxfordshire and in other British coalfields is reviewed. The ranges of these species provide the basis for recognising three new miospore assemblage zones to replace the former Thymospora obscura Assemblage Zone XI of Smith \& Butterworth (1967). The base of the epibole of Thymospora pseudothiessenii is also well defined and is a useful biostratigraphic marker. Comparison is made with the zonal sub-division of the Desmoinesian series of the Illinois basin by Peppers (1985).
\end{abstract}

\section{INTRODUCTION}

The presence, near Burford in Oxfordshire, of supposedly barren Upper Coal Measures under Mesozoic rocks has been known for just over 100 years but seams of workable thickness were only discovered when the British Geological Survey borehole at Apley Barn was sunk in 1960-61 near Witney (Poole, 1969). Subsequently, two further B.G.S. boreholes at Steeple Aston (Poole, 1977) and Withycombe Farm near Banbury (Poole, 1978) also proved workable seams. The possible limits of the coalfield were suggested by Dunham \& Poole (1974).

The miospore assemblages from seams in these boreholes are characteristic of seams of Westphalian D age and tentative correlations between these boreholes, based on the stratigraphic ranges of a limited number of miospores, have been proposed (Smith in Poole, 1977, 1978).

In December 1975, the National Coal Board began a programme of exploratory boring in the area between Oxford and Coventry. The resulting information from a large number of relatively closely spaced boreholes has made possible the detailed correlation of the main coal bearing horizons across the area. There is thus a sound basis from which to examine the stratigraphic ranges of selected miospores in the Oxfordshire Coalfield. The coals are of relatively low rank and therefore represent the fullest succession of seams of Westphalian D age in Britain from which spores can be readily isolated.
As a result of recent work, the species and the ranges proposed earlier have been emended and a scheme for zoning the Upper Coal Measures of Oxfordshire is proposed. It is only concerned with species of proven value for correlation purposes and not with the total assemblage.

\section{GEOLOGY}

In Oxfordshire and southeast Warwickshire, up to $1000 \mathrm{~m}$ of Upper Coal Measures rocks occur, comprising mudstones, sandstones and coals. A variable amount of reddening is developed in the upper portions. No marine horizons are represented in these rocks, which lie unconformably on strata of Cambrian to Devonian age. Strata, in some cases with coal seams, of Middle and possibly Lower Coal Measures age are frequently present at the base of the succession. They occur over a wide area and in many boreholes are separated from the seams of Upper Coal Measures age by igneous rocks varying in thickness from a few centimetres to $165 \mathrm{~m}$ in the Steeple Aston Borehole. Nowhere in the coalfield is there a conformable development of seams from the Middle to the Upper Coal Measures. The Coal Measures rocks are, in turn, overlain unconformably by Mesozoic rocks.

In the Upper Coal Measures, the thickness of coal bearing strata is greater in Oxfordshire than in southeast Warwickshire due to the influence of the Midland 
Barrier on the process of sedimentation and erosion in the two areas. At Apley Barn, the southernmost of the boreholes examined, some 40 coal seams, the majority thin, are developed in the Upper Coal Measures. The thickness of coal bearing strata is $804 \mathrm{~m}$. Moving in a northerly direction, both the number of seams and the thickness of coal bearing strata decreases until at Southam the number of seams is reduced to approximately 10 in some $215 \mathrm{~m}$ of strata. Over most of southeast Warwickshire there are only three seams in $100 \mathrm{~m}$ of strata and the lower seams in the Upper Coal Measures are missing from the succession. However, the total thickness of Upper Coal Measures (Fig. 2) in the boreholes in the Coventry area, some $15 \mathrm{~km}$ north of Warwick, exceeds that at Withycombe Farm, near Banbury, due to the accumulation and subsequent preservation of a considerable thickness of barren Upper Coal Measures strata above the coal bearing strata.

The rates of subsidence presumably varied in different parts of the coalfield. Thus at Apley Barn the main coal horizons are represented by many seams and the rate of subsidence must have been rapid compared with the more northerly areas with fewer seams of equivalent age. However, there is no increase in the thickness of individual seams north of Banbury associated with reduced subsidence rates, at least in the boreholes examined. At Apley Barn the total thickness of coal exceeds that of the equivalent horizons farther north. At Southam, for example, many of the seams are thin and dirty.

These facts have a bearing on the development of peat facies (coal lithotypes) and species diversity. Both tend to optimum development in thick coals.

\section{STRATIGRAPHY}

At Apley Barn, the B.G.S. has divided the Upper Coal Measures rocks into five lithological formations, which have been named, in descending order:-

Windrush Formation

Burford Coal Formation

Crawley Formation

Witney Coal Formation

Arenaceous Coal Formation

These formations were subsequently recognised in the Steeple Aston borehole but, at Withycombe Farm, the strata have been correlated with those parts of the Keele and Halesowen Formations of the Southern English Midlands Coalfields lying to the north and northwest (Poole, 1978, p. 16). The base of the Windrush Formation is roughly equivalent to the base of the Keele Formation in the boreholes of southeast Warwickshire.

With the additional geophysical and chemical information from the relatively closely spaced N.C.B. boreholes, it has been possible not only to recognise and correlate the broad lithological horizons but to demonstrate the lateral persistence of the main seams in the principal coal bearing horizons. Thus, the horizon that corresponds to the base of the Keele and Windrush Formations is better defined by the coal seam which occurs at this level, than by the lithological features, such as reddening of the strata which may not be a contemporary event and is an unreliable basis for chronostratigraphic correlation. The correlation of individual beds within formations, however, is sometimes difficult, particularly where, at a given horizon, there is a discrepancy between the number of leaves in adjacent boreholes. Unfortunately, palynological methods are rarely able to assist correlation in these instances.

The broad correlations which have been established by non-palynological means have been used as a basis for comparing the stratigraphic ranges of selected spores in the different boreholes.

\section{LOCATION OF BOREHOLES AND SEAMS EX- AMINED}

Fig. 1 shows the location of the nine boreholes which were the sources of the coals used in this investigation. The boreholes were selected to provide a roughly N-S section through the coalfield from Apley Barn in the south to Southam in the north. The Kineton and Southam boreholes are located in the South Warwickshire Prospect. The distance between the extreme boreholes is approximately $50 \mathrm{~km}$.

The main seams have been named by R. F. Goossens to assist in correlation and their usage is well established within the N.C.B. The representation of these seams in the boreholes examined is shown in Fig. 2. Named seams may comprise several beds of coal separated by dirts. Unless otherwise indicated, at least one member of each of the important groups of seams in each borehole has been examined for spores. This diagrammatic presentation of the succession conceals the northward thinning of coal bearing strata and the considerable reduction in the number of seams referred to above.

\section{PETROGRAPHY OF THE COALS}

Few palynologists consider the evidence which a coal provides on the environment in which it was formed and the possible effect of that environment on the plants growing on the deposit and on the derived miospore assemblages. The petrographic differences between seams may be due to one or more of the following influences: climate, the depositional environment and the seral changes in the vegetation taking place during the growth of the deposit. They may also reflect differences in the diagenetic and catagenetic stages of coalification resulting from geological processes. Petrographic differences attributable to the latter 


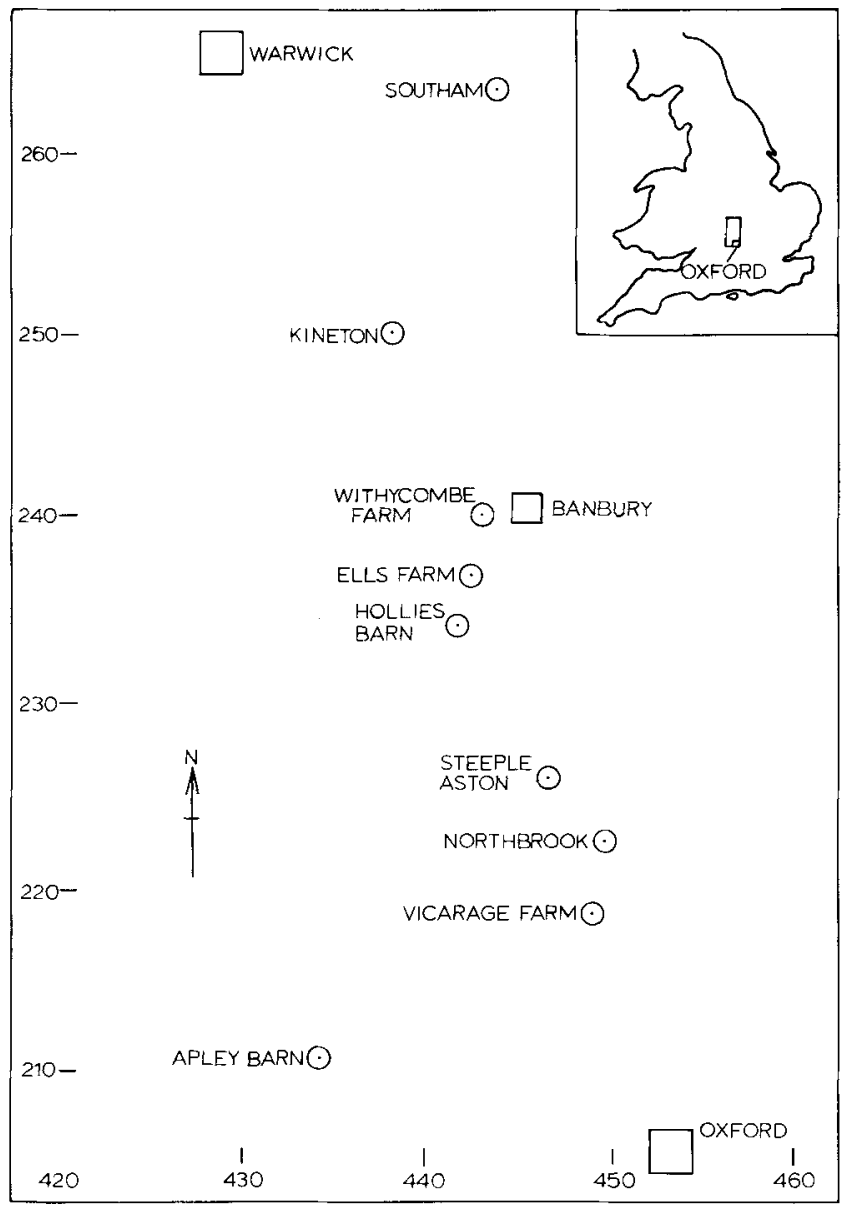

Fig. 1. Location of B.G.S. and N.C.B. boreholes referred to in the text.

cause will not be reflected in the floral record. To assist in the interpretation of the petrographic evidence Styan \& Bustin (1983 a \& b) have investigated the microstructure of a modern delta peat deposit in an attempt to trace the origin of the petrographic components of Hard coals.

Harvey \& Dillon (1985) were able to demonstrate both long term changes of maceral composition which they related to climatic conditions, and short term variations in maceral composition within individual seams which they attributed to localised palaeoenvironmental influences. They record an enrichment of inertinite in coals belonging to the Missourian Series in Illinois when compared with the older Desmoinesian coals. The latter are believed to be equivalent to European coal of Westphalian D age. This change was considered to mark the onset of a drier climatic regime, which according to Phillips et al. (1974) and Phillips \& Peppers (1984) was responsible for the change of the dominant peat forming vegetation from arborescent lycopods to tree ferns and no doubt accounts for the increasing proportion of monolete spores in the younger seams of the Upper Coal Measures in Britain.

The broad relationships between petrography and spore assemblages have been established for British coals of Middle and Lower Coal Measures age (Smith, $1962,1964)$. No study has been made of coals of Upper Coal Measures age in Britain although coals of this age from the Saar-Lorraine basin have been studied by Navale (1964) and Alpern et al. (1964). Such studies depend on a fine subdivision of the seam profile for petrographic and spore analyses. Such investigations have not been made on the seams in the Oxfordshire coalfield but, nevertheless, some observations can be made by comparing the petrography of these seams with those from older horizons on a whole seam basis.

The most meaningful technique for characterising the composition of the coal-peat is to determine its microlithotype content (I.C.C.P., International Handbook of Coal Petrography, 1963, 1971, 1976). Microlithotypes are the natural associations of macerals (the basic organic components of coal) broadly corresponding to the different coal lithotypes which are recognisable by eye without the aid of a microscope.

Table 1 compares the average microlithotype composition of the seams in a southeast Warwickshire borehole and two Oxfordshire boreholes (located at the extremes and in the middle of the N/S transect across the coalfield) with the composition of seams from the Upper, Middle and Lower Coal Measures of Yorkshire. It can be seen that the Oxfordshire seams are enriched in the bright coal microlithotypes (vitrite and clarite) and deficient in durite (the main component of dull coal) compared with the older seams in Yorkshire, but do not differ significantly in composition from the seam in the Upper Coal Measures of Yorkshire. The mean of the combined totals of vitrite and clarite in the individual seams from the three boreholes is $74 \%$ ranging from 42-96\%. However, four seams from Withycombe Farm have combined totals of these microlithotypes of less than $60 \%$. These seams all contained between $35-43 \%$ of trimacerite which is significantly above the average value of seams in the Oxfordshire coalfield. These seams tend to be among the thinner seams, which is unexpected. In general, thicker seams tend to have a greater diversity of microlithotypes. The seams at Southam, where the succession is condensed, are also thin, and several contain significant amounts of pyrite, carbonaceous shale and shale.

The scarcity of Densospores and the absence of crassidurite from the seams in the Oxfordshire Basin is unlikely to be due to climatic influence since the genus occurs in contemporary strata in the Bristol and Somerset Coalfields. It suggests that the hydrological conditions associated with the occurrence of Densospores were lacking in the Oxfordshire Basin in Upper 


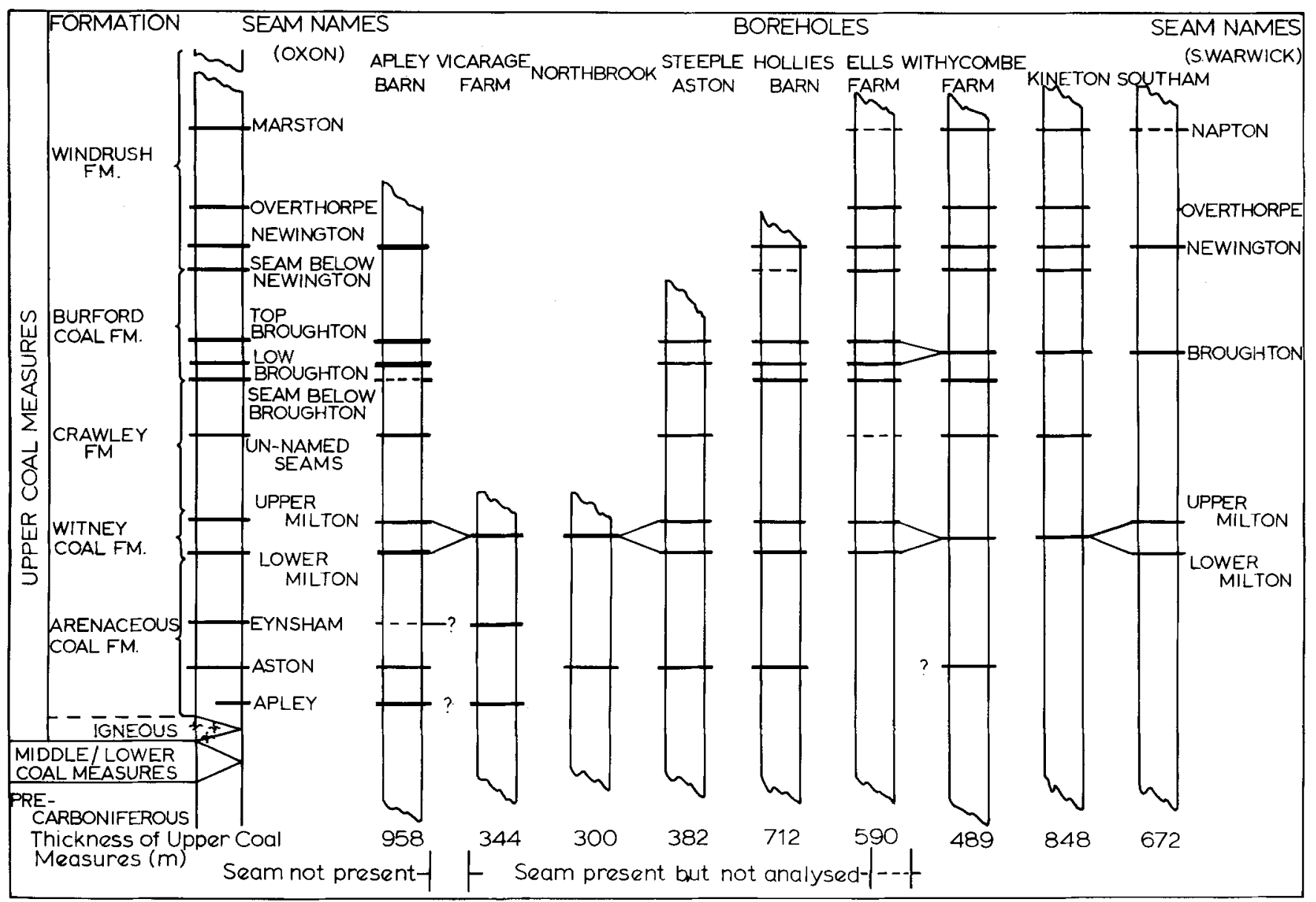

Fig. 2. Generalised section of the Upper Coal Measures of the Oxfordshire Coalfield and the representation of the main seams in the selected boreholes.

Coal Measures times. In the contemporary Bristol and Somerset strata and in the Lower and Middle Coal Measures in other paralic basins in Britain, the environmental conditions associated with the formation of many of the thicker seams intermittently favoured the growth of plants producing the larger forms of Densosporites, apparently to the exclusion of most other plants. At these Densospore rich horizons the processes of decay and preservation of organic matter were also different, in so far as it is preserved as macrinite rather than vitrinite.

Tenuidurite is also scarce in the Oxfordshire seams, the greatest amount being 7\% in the upper bed of the Apley Seam at Apley Barn. This seam also contained $14 \%$ of cannel coal. The amounts of fusite are not significantly different from the amounts in the seams of Middle Coal Measures age.

It is reasonable to assume that the mainly bright coals of the Oxfordshire Coalfield represent the formation of autochthonous or subautochthonous peat in a more or less rapidly subsiding basin where the organic matter was relatively well preserved under waterlogged anaerobic conditions. Peat formed under these conditions might be expected to support relatively few types of vegetation and overall to have a relatively poor diversity of miospores. In contrast are the petrographically variable seams of the Lower and Middle Coal Measures. In the case of these seams, subsidence was probably interrupted or peat growth may have exceeded the amount of subsidence. Ground water levels probably showed greater fluctuations with the result that part of the peat was periodically exposed to relatively aerobic conditions. Peat formed under these varying conditions would provide a greater diversity of habitat type and vegetation.

An example from Oxfordshire of a petrographic difference between seams unrelated to their miospore assemblages is the occurrence of significant amounts of structureless vitrite including pseudovitrinite in seams from the Apley Barn Borehole and the occurrence of vitrinite with a patchy texture in the coals from the other two boreholes. Jones et al. (1984) have suggested that such differences may be the result of different coalification gradients. 


\begin{tabular}{|c|c|c|c|c|c|c|c|c|c|}
\hline \multirow[t]{2}{*}{ Source } & \multicolumn{2}{|c|}{ Number of } & \multicolumn{7}{|c|}{ Microlithotypes (volume percent) } \\
\hline & Seams & Samples & Vitrite & Clarite & Trimacerite & Durite & Fusite & Vitrinertite & $\begin{array}{c}\text { Carbominerite } \\
\text { Carbopyrite }\end{array}$ \\
\hline \multicolumn{10}{|l|}{$\begin{array}{l}\text { Oxfordshire/ } \\
\text { S.E. Warwickshire } \\
\text { Upper CM }\end{array}$} \\
\hline Apley Barn BH & 15 & & $\begin{array}{c}47 \\
(28-63)\end{array}$ & $\begin{array}{c}25 \\
(13-43)\end{array}$ & $\begin{array}{c}19 \\
(7-34)\end{array}$ & $\begin{array}{c}1 \\
(0-7)\end{array}$ & $\begin{array}{c}4 \\
(1-9)\end{array}$ & 1 & 3 \\
\hline Withycombe Fm BH & 10 & & $\begin{array}{c}43 \\
(32-52)\end{array}$ & $\begin{array}{c}27 \\
(10-48)\end{array}$ & $\begin{array}{c}23 \\
(3-43)\end{array}$ & $\begin{array}{c}1 \\
(0-5)\end{array}$ & $\begin{array}{c}4 \\
(1-10)\end{array}$ & 1 & 1 \\
\hline Southam BH & 6 & & $\begin{array}{c}54 \\
(48-58)\end{array}$ & $\begin{array}{c}31 \\
(23-35)\end{array}$ & $\begin{array}{c}8 \\
(5-13)\end{array}$ & $\begin{array}{c}1 \\
(0-2)\end{array}$ & $\begin{array}{c}3 \\
(2-6)\end{array}$ & $<0.5$ & 3 \\
\hline \multicolumn{10}{|l|}{$\begin{array}{l}\text { Yorkshire } \\
\text { (Section worked } \\
\text { excl. gross dirt) }\end{array}$} \\
\hline Upper CM & 1 & 7 & $\begin{array}{c}48 \\
(43-59)\end{array}$ & $\begin{array}{c}28 \\
(20-36)\end{array}$ & $\begin{array}{c}17 \\
(6-25)\end{array}$ & $\begin{array}{c}1 \\
(0-2)\end{array}$ & $\begin{array}{c}4 \\
(2-6)\end{array}$ & n.d. & 2 \\
\hline Middle $\mathrm{CM}$ & 5 & 45 & $\begin{array}{c}42 \\
(22-58)\end{array}$ & $\begin{array}{c}20 \\
(8-35)\end{array}$ & $\begin{array}{c}21 \\
(8-34)\end{array}$ & $\begin{array}{c}10 \\
(2-27)\end{array}$ & $\begin{array}{c}6 \\
(2-14)\end{array}$ & n.d. & 1 \\
\hline Lower CM & 6 & 51 & $\begin{array}{c}42 \\
(24-57)\end{array}$ & $\begin{array}{c}25 \\
(16-39)\end{array}$ & $\begin{array}{c}20 \\
(6-36)\end{array}$ & $\begin{array}{c}6 \\
(1-22)\end{array}$ & $\begin{array}{c}6 \\
(2-12)\end{array}$ & n.d. & 1 \\
\hline
\end{tabular}

Table 1. Microlithotype composition of seams from the Oxfordshire Coalfield (Upper Coal Measures) and Yorkshire Coalfield (Upper, Middle and Lower Coal Measures).

\section{SYSTEMATIC DESCRIPTIONS}

Turma Triletes (Reinsch) Dettmann, 1963

Suprasubturma Acavatitriletes Dettmann, 1963

Subturma Azonotriletes (Luber) Dettmann, 1963

Infraturma Apiculati (Bennie and Kidston) Potonié, 1956

Subinfraturma Verrucati, Dybova \& Jachowicz, 1957 Genus Schopfites Kosanke, 1950

Type species Schopfites dimorphus Kosanke, 1950

(PI. 2, figs. 22-24)

Remarks. Peppers (1985), in his comparative studies of the ranges of miospores in Illinois and in Western Europe, recognises two species, $S$. dimorphus and $S$. colchesterensis Kosanke, 1950 and used the name of the latter species to designate an assemblage zone. In the present work all forms of Schopfites have been assigned to $S$. dimorphus for the reasons given in Smith \& Butterworth (1967). A smaller, less coarsely ornamented form referred to Schopfites sp. by Peppers (1985) and to S. colchesterensis by Loboziak (1971 pl. 4, fig. 25) was not seen in the present work.

Occurrence. Smith \& Butterworth (1967) assumed the species to occur throughout the Westphalian D of Great Britain. However in Oxfordshire it is now known to have a more restricted stratigraphic range occurring in seams between the base of the Witney Coal Formation and the base of the Windrush Coal Formation. Re-examination of its occurrence elsewhere suggests that its range may be similar to that in Oxfordshire. It may be found in most seams as a scarce component of the miospore flora. seldom exceeding $0.4 \%$ of the total seam assemblage.

Turma Monoletes Ibrahim. 1933

Suprasubturma Acavatomonoletes Dettmann, 1963

Subturma Azonomonoletes Luber, 1935

Infraturma Sculptatomonoletes Dybova \& Jachowicz, 1957

Genus Punctatosporites (Ibrahim 1933. Krutzsch 1959) Alpern \& Doubinger. 1973

Type species $P$. minutus (Ibrahim) Alpern \& Doubinger, 1973

Punctatosporites granifer (Potonié \& Kremp 1956) Alpern \& Doubinger, 1973

(Pl. 2, figs. 1-8)

Remarks. The figures show the range of size, shape and ornament of forms assigned to $P$. granifer by the author. Some of these forms resemble specimens assigned to $P$. minutus and $P$. rotundus Bharadwaj, 
1957 by Alpern \& Doubinger (1973) in their revision of Palaeozoic monolete genera. However, the author has assigned to $P$. granifer all monolete spores without a pseudocingulum, within the emended size range 14$42 \mu \mathrm{m}$ (Alpern \& Doubinger, 1973) and with a distinctly granulate ornament clearly visible at low powers of magnification $(\times 10$ objective). The grana clearly project at the amb. Monolete spores with scabrate ornament and with a smooth amb. are assigned to $P$. punctatus (Kosanke) Alpern and Doubinger or $P$. minutus. It is significant that Van Wijhe \& Bless, 1974 refer to the distinctive appearance of forms of $P$. granifer occurring in the upper Westphalian $\mathrm{C}$ and
Westphalian D of the Netherlands. These forms are relatively large, frequently less regularly oval and possess a thicker exine than specimens from the lower part of the Westphalian C.

Occurrence. Smith \& Butterworth (1967) gave the stratigraphic range of the species as the Westphalian C and D of Great Britain without the knowledge of the precise age of the coals examined. In Oxfordshire the species occurs throughout the Arenaceous and Witney Coal Formations. It occurs in most seams, with an abundance generally between $1 \%$ and $3 \%$ of the seam assemblage; maximum recorded abundance $8 \%$.

\title{
Explanation of Plate 1
}

\author{
All figures are $\times 500$
}

Figs. 1-7. Vestispora burfordiensis sp. nov. (figs. 1-6, from type locality).

Fig. 1. Holotype, oblique polar compression; preparation T/129/1.

Fig. 2. Paratype, equatorial compression; operculum partly detached, several relatively narrow encircling costae running parallel to the equator; preparation T/129/2.

Fig. 3. Oblique polar compression. Note smooth amb and thickness of exoexine as seen at margin; laesura and operculum faintly visible, poor costal development.

Fig. 4. Partial spore with distinct foveo-reticulate ornament and unusually well developed costae projecting from amb.

Fig. 5. Equatorial compression; split between operculum and remainder of exoexine, costae indistinct.

Fig. 6. Torn exine, one narrow encircling costa and several incompletely preserved/developed costae.

Fig. 7. Pseudo reticulate pattern formed by crossing costae on opposing surfaces of exoexine, seam at $676.68 \mathrm{~m}$ Apley Barn Borehole, Crawley Formation.

Figs. 8-13. Vestispora witneyensis sp. nov.

Fig. 8. Holotype, oblique polar compression, aperture on proximal face left by partially detached operculum, single well-defined encircling costa; preparation $\mathrm{T} / 130 / 1$.

Fig. 9. Paratype, oblique polar compression, operculum in situ but incipient suture clearly visible, costae thin and indistinct; preparation $\mathrm{T} / 130 / 2$.

Fig. 10. Laesura showing through aperture left by detached operculum, seam at $676.68 \mathrm{~m}$ Apley Barn Borehole, Crawley Formation.

Fig. 11. Equatorial compression with operculum partly detached but still in contact with part of exoexine; compare ornamentation of operculum with that in fig. 2; specimen from type locality.

Fig. 12. A large specimen with well-developed evenly spaced costae to one side, passing over the amb but hardly projecting, seam at $676.68 \mathrm{~m}$ Apley Barn Borehole, Crawley Formation.

Fig. 13. Specimen with detached operculum and poorly developed costae; note the crenulate appearance of the amb due to the foveolate ornament, specimen from type locality.

Figs. 14-17. Vestispora magna (Butterworth \& Williams) Wilson \& Venkatachala, 1963, from type locality.

Fig. 14. Equatorial compression, well-defined broad costae encircling spore parallel to the quator and projecting at amb.

Fig. 15. Small specimen showing fine reticulate ornament but lacking distinct costae.

Figs. 16, 17. Two specimens showing fine and coarse reticulation, the latter produced by branching costae. 

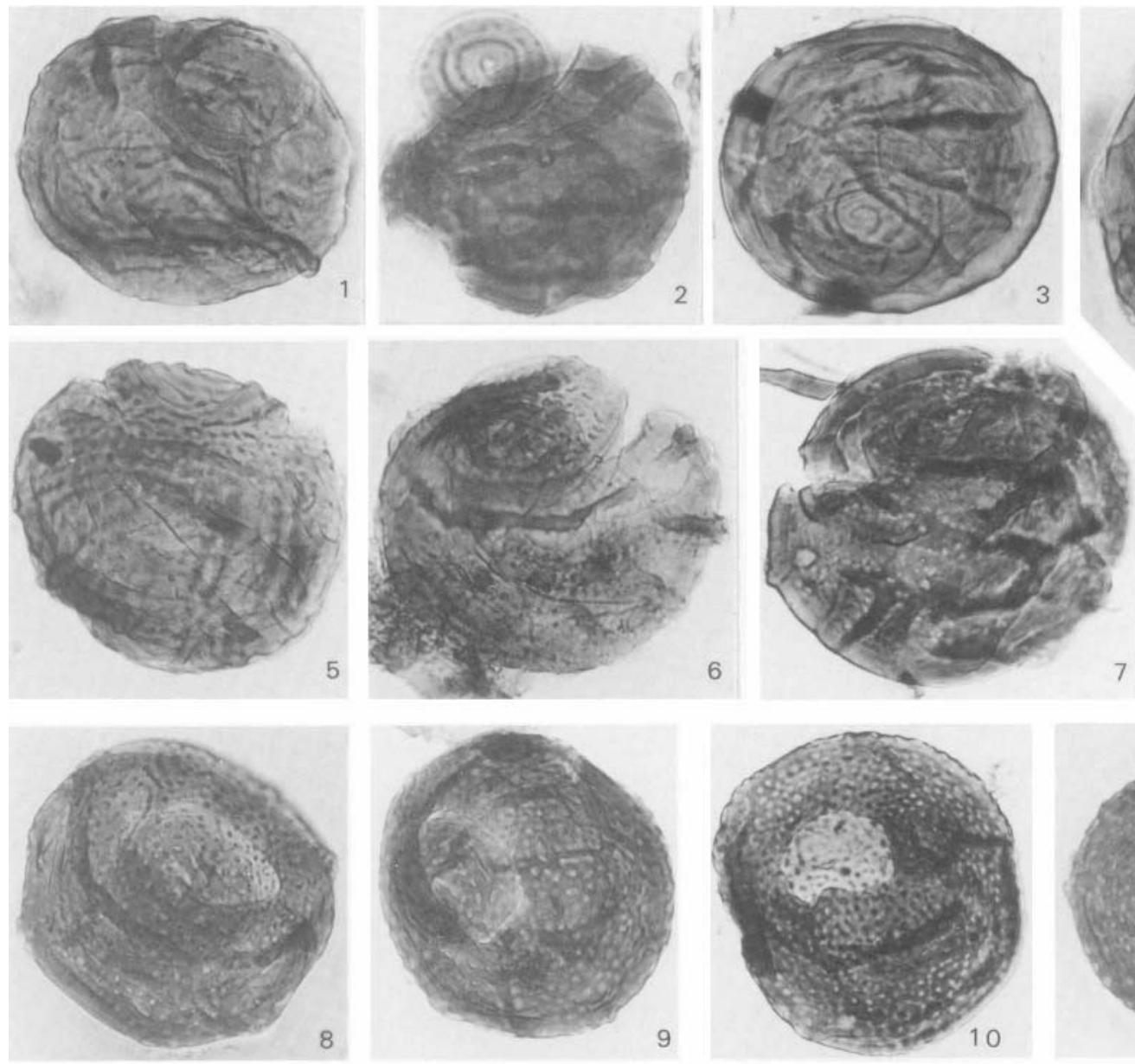
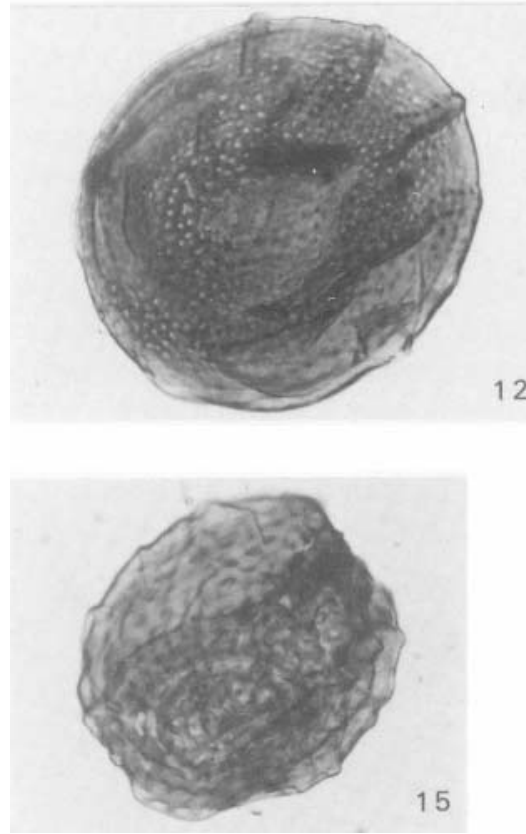
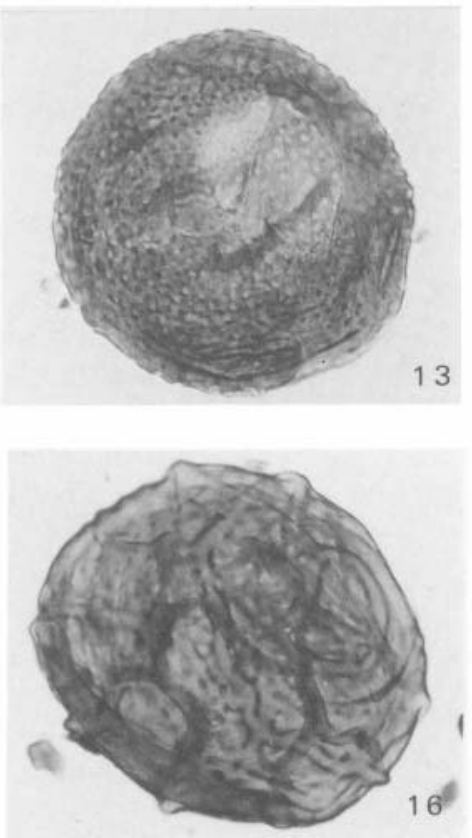
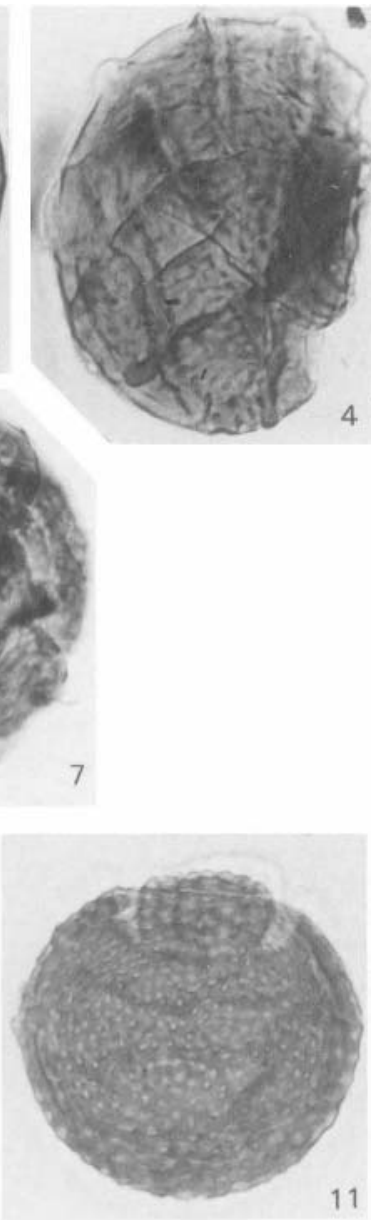

11
3

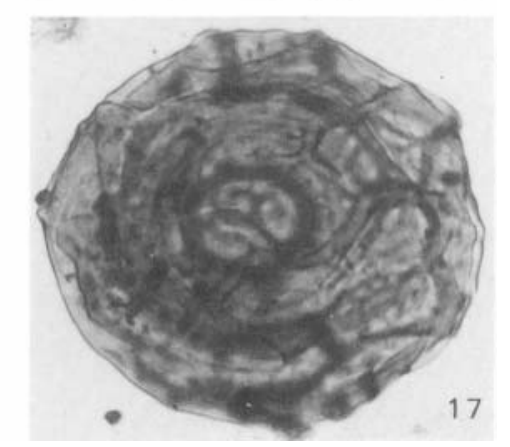


Genus Thymospora (Wilson \& Venkatachala, 1963) Alpern \& Doubinger, 1973

Type species T. thiessenii (Kosanke) Wilson \& Venkatachala, 1963

Thymospora pseudothiessenii (Kosanke, 1950) Alpern \& Doubinger, 1973

(Pl. 2, figs. 9-21)

Remarks. The figures show the range of size and considerable variation of ornament of spores assigned to $T$. pseudothiessenii. In earlier work on the Oxfordshire Coalfield, Smith in Poole $(1977,1978)$ assigned the forms with extremely coarse ornament to $T$. perverrucosa (Alpern, 1959) Wilson \& Venkatachala, 1963 and considered the species to have stratigraphic significance. The subsequent detailed study of all forms of Thymospora shows that spores with ornament intermediate between $T$. perverrucosa and $T$. pseudothiessenii occur, thus making the recognition of these species a subjective matter. This accords with the emended diagnosis of $T$. pseudothiessenii by Alpern \& Doubinger (1973). Thus, whilst the coarse forms are more likely to be found in seams above the base of the epibole of the genus, the species can no longer be regarded as having stratigraphic significance within the Westphalian D.

Occurrence. Oxfordshire Coalfield, ranges throughout the Westphalian D. It is uncommon in the seams of the Arenaceous and Witney Coal Formations and in the Crawley Formation, seldom exceeding $0.4 \%$ of the total assemblage. In the Burford Coal and Windrush Coal Formations it generally exceeds $1 \%$ and may exceed $10 \%$ of the assemblage. The base of its epibole occurs at the horizon of the Low Broughton Seam. The species may show considerable variation in its abundance within the same seam.

Turma Hilates Dettmann, 1963

Suprasubturma Cavatihilates Smith \& Butterworth, 1967

Subturma Azonocavatihilates Smith \& Butterworth, 1967

Infraturma Epitygmati (Spode) Smith \& Butterworth, 1967

Genus Vestispora (Wilson \& Hoffmeister) Wilson \& Venkatachala, 1963

Type species $V$. profunda Wilson \& Hoffmeister, 1956 Vestispora burfordiensis sp. nov.

(P1. 1, figs. 1-7)

Derivation of name. The specific name refers to the type stratum.

Diagnosis. Miospores, radial, trilete, amb circular to subcircular. Relatively thick operculate exoexine with fine foveo - reticulate ornament overlain by open system of relatively coarse unbranched encircling costae. Operculum more coarsely ornamented. Costae may project slightly beyond amb. Inner body and laesura seldom seen.

Holotype. Pl. 1, fig. 1. Preparation T/129/1 in collection of N.C.B. Yorkshire Regional Laboratory.

Paratype. Pl. 1, fig. 2. Preparation T/129/2.

Locality and horizon. Apley Barn Borehole, Oxfordshire, England. Top Broughton Seam at 492.46m. Burford Coal Formation, Upper Coal Measures.

Description. In lateral compression the proximal surface bearing the operculum often appears flattened. Eoexine thickness $2.5-3.7 \mu \mathrm{m}$, generally recognisable at margin of spore as clear rim. Foveo-reticulate ornamentation weakly to strongly developed. Muri about $1.5-2.5 \mu \mathrm{m}$ in width, lumina $1.5-3.5 \mu \mathrm{m}$, shape variable but generally polygonal. Costae usually prominent and unbranched $3 \mu \mathrm{m}$ in width. May project at amb up to $5 \mu \mathrm{m}$ but often hardly recognisable. Generally two to four costae encircle the spore. Mean size of the operculum $33 \mu \mathrm{m}$ measurable in about half the specimens. Muri on operculum tend to form a concentric pattern with lumina somewhat larger and more irregular in shape than on the remainder of exine.

Dimensions. 55 (70) $84 \mu \mathrm{m}$ (23 specimens macerated in fuming nitric acid). Holotype $78 \mu \mathrm{m}$.

Remarks. The lumina are similar to those of $V$. luminata Ravn in size and shape but the latter species lacks costae.

Comparison. Two other species $V$. pseudoreticulata (Spode) in Smith \& Butterworth, 1967 and V. magna (B.utterworth \& Williams) Wilson \& Venkatachala, 1963 have a dual component exoexine ornament. $V$. pseudoreticulata may be distinguished by its less prominent, narrower carinate costae and $V$. magna by the reticulate pattern of its fine and coarse ornamentation. The muri comprising the latter clearly project at the amb.

Occurrence. Oxfordshire Coalfield, range in the coals extends from the upper part of the Witney Coal Formation (Upper Milton Seam) to the base of the Windrush Coal Formation (Newington Seam). Except for the Upper Milton Seam in which it is sporadic, it is generally present but with an abundance of $<0.1 \%$ of the seam assemblage.

\section{Vestispora witneyensis sp. nov.}

(P1. 1, figs. 8-13)

Derivation of name. The specific name refers to the type stratum.

Diagnosis. Miospores, radial, trilete, amb circular. Relatively thick operculate exoexine with fine foveolate ornament overlain by a poorly developed open system of relatively narrow unbranched costae. 

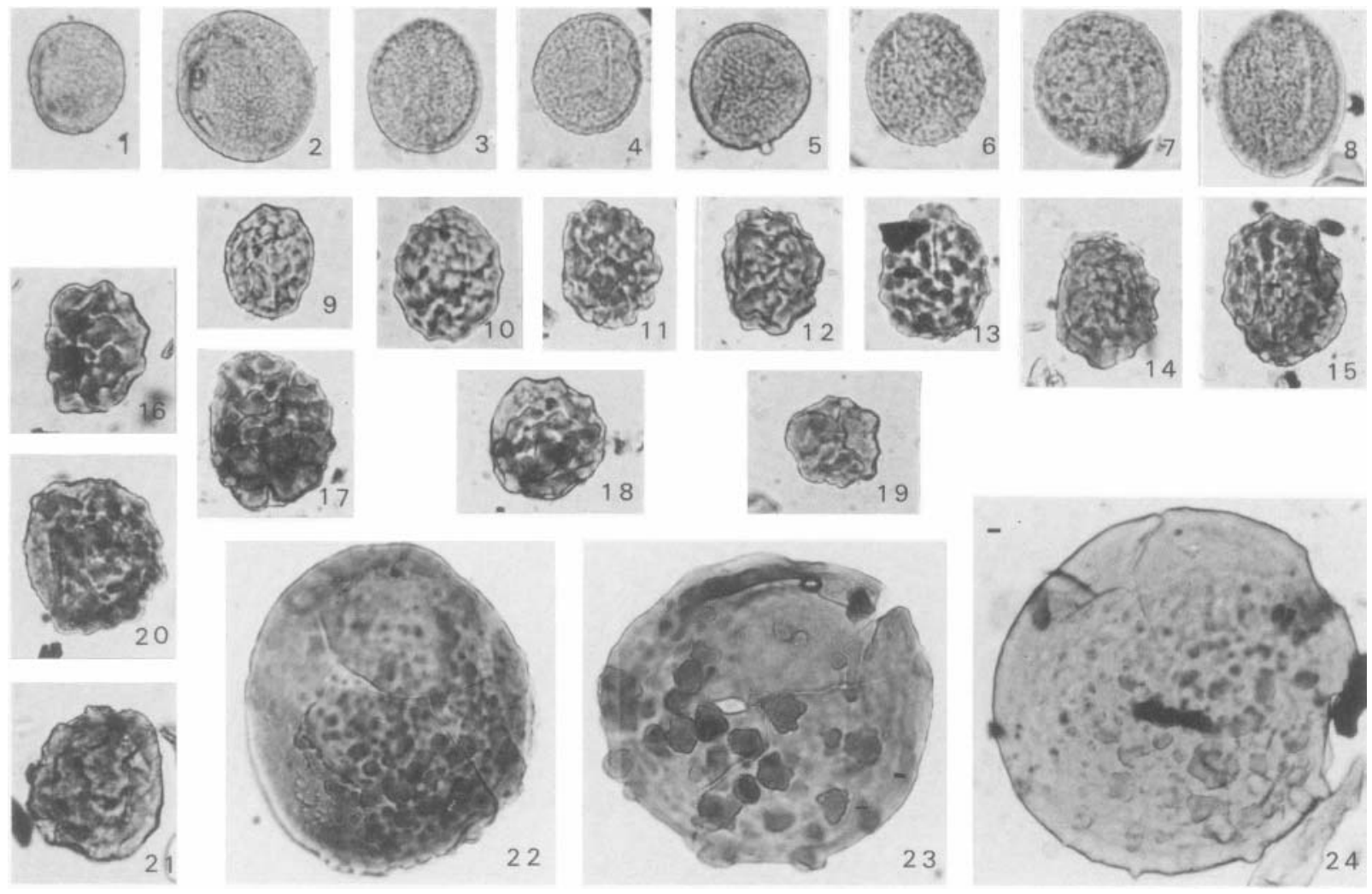

\section{Explanation of Plate 2}

All figures are $\times 500$

Figs. 1-8. Punctatosporites granifer (Potonié \& Kremp) Alpern \& Doubinger, 1973 (figs. 1, 2, 4, 8, seam at 467.40m

(Lower Milton), Steeple Aston Borehole, Witney Formation; figs. 3, 5, 6, 7, seam at 836.44m (? Aston), Withycombe Farm Borehole, Arenaceous Coal Formation).

Figs. 1, 2. Small and large specimens with fine grana.

Figs. 3, 4, 5. Oval and round specimens with medium sized grana.

Figs. 6, 7, 8. Specimens with coarse grana; fig. 8, specimen with thickened exine giving appearance of pseudo-cingulum.

Figs. 9-21. Thymospora pseudothiessenii (Kosanke) Alpern \& Doubinger, 1973 (figs. 9-13, 15-19, seam at 586.93m (Overthorpe) Withycombe Farm Borehole, Windrush Formation; fig. 14, seam at $637.30 \mathrm{~m}$ (bottom leaf of Newington) Hollies Barn Borehole, Windrush Formation; figs. 20, 21, seam at $714.65 \mathrm{~m}$ (Top Broughton) Hollies Barn Borehole, Burford Coal Formation).

Figs. 9, 10. Specimens with fine ornament.

Figs. 11-15. Specimens with medium sized ornament; fig. 14, specimen with pseudo-cingulum.

Figs. 16-19. Specimens with coarse ornament, formerly assigned to T. perverrucosa (Alpern) Wilson and Venkatachala 1963.

Fig. 17. Specimen showing approach to Torispora type crassitude.

Figs. 20, 21. Large specimens with fine grana interspersed among coarse ornament.

Figs. 22-24. Schopfites dimorphus Kosanke, 1950 (figs. 22, 23, seam at 450.84m (Upper Milton) Steeple Aston

Borehole, Witney Coal Formation; fig. 24, seam at 492.46m (Top Broughton) Apley Barn Borehole, Burford Coal Formation). Specimens to show variation in size and density of distal ornament. 
Costae hardly project beyond amb. Inner body and laesura seldom seen.

Holotype. Pl. 1, fig. 8. Preparation T/130/1 in collection of NCB Yorkshire Regional Laboratory.

Paratype. P1. 1, fig. 9. Preparation T/130/2.

Locality and horizon. Steeple Aston borehole, Oxfordshire, England. Upper Milton Seam at $450.84 \mathrm{~m}$, Witney Coal Formation, Upper Coal Measures.

Description. Distinctly foveolate ornament, fovea circular to oval, mean diameter $2 \mu \mathrm{m}$ and approximately the same distance apart. Operculum is similarly ornamented. Costae relatively weak, few in number, narrow $1.5-3.0 \mu \mathrm{m}$ in width, often fragmentary. Only the most strongly developed costae project beyond the amb. but not by more than $2.5 \mu \mathrm{m}$. Operculum often partly detached or missing.

Dimensions. 63 (73.5) $87 \mu \mathrm{m}$ (19: specimens, macerated in fuming nitric acid). Holotype $75 \mu \mathrm{m}$.

Remarks. The fovea closely resemble those of $V$. fenestrata (Kosanke \& Brokaw) Wilson \& Venkatachala, 1963. However $V$. fenestrata lacks costate sculpture. Comparison. Differs from $V$. burfordiensis sp. nov. in having distinctly foveolate ornament and poorly developed costae.

Occurrence. Oxfordshire Coalfield, range in the coals extends from the middle of the Arenaceous Coal Formation to the upper part of the Burford Coal Formation. Below the Upper Milton Seam it is only sporadic but at other horizons within its range it occurs regularly but with an abundance of $<0.1 \%$ of the seam assemblage.

Vestispora magna (Butterworth \& Williams, 1954) Wilson \& Venkatachala, 1963

(P1. 1, figs. 14-17)

Remarks. The figured specimens are from the type material and have been included to show some of the variation in exoexine ornament for comparison with $V$. burfordiensis sp. nov. and $V$. witneyensis sp. nov.

\section{RANGES AND ABUNDANCE OF SELECTED SPORES IN COAL SEAMS OF UPPER COAL MEASURES OF OXFORDSHIRE AND S.E. WARWICKSHIRE}

The species listed by Smith \& Butterworth (1967), as being characteristic of their Assemblage Zone XI, were assumed by these authors to range throughout their Zone. The absence of a species from a particular horizon was not regarded as significant because of the somewhat fragmentary nature of the seam successions examined and the often sporadic ocurrence of species within these successions. Also, although many samples were examined, they were often representative of thin seams whose precise correlation and stratigraphic position is uncertain.

With the exploration in Oxfordshire the opportunity became available to examine the ranges of species through a continuous succession of seams. The work on the three B.G.S. boreholes (Smith in Poole, loc. cit.) suggested that certain species had restricted ranges which could serve a useful stratigraphic purpose. The subsequent work on coals from the N.C.B. boreholes, involving the systematic study of the morphographic variations within the populations of the species in question, has made it necessary to modify the earlier conclusions. In particular, the coarsely verrucate forms of Thymospora referred to $T$. perverrucosa are now considered to represent an extreme development of the ornamentation of $T$. pseudothiessenii and the form referred to Vestispora of $V$. magna has been resolved into two new species of Vestispora with overlapping ranges.

Table 2 shows the frequency of occurrence of five species of miospores of proven stratigraphical value in the correlation of the Upper Coal Measures of Oxfordshire. The numerical abundance of these species is summarised below.

$T$. pseudothiessenii only occurs sporadically in the assemblages from seams of the Arenaceous and Witney Coal Formations and the Crawley Formation with a frequency generally $<0.1 \%$ and only once exceeding $0.4 \%$ of the total assemblage. It is present in most seams of the Burford Coal Formation and Windrush Formation often exceeding $2 \%$ of the assemblage and reaching $14 \%$ in the Overthorpe Seam at Withycombe Farm. The base of the epibole occurs at the horizon of the Low Broughton Seam. It is, however, less abundant in seams at these horizons in the Kineton and Southam boreholes and is apparently absent from the assemblages from the Witney Coal Formation in these boreholes. However, in the Kineton borehole the species is well represented (3\%) in the Marston (Napton) Seam, the youngest seam in the Windrush Formation.

Vestispora burfordiensis is a relatively uncommon $(<0.1 \%)$ but persistent member of the assemblages from coal seams in the Burford Coal and Crawley Formations. Outside this range it was rarely recorded from the Newington and Upper Milton seams.

Schopfites dimorphus is a distinctive spore which is not easily overlooked. It ranges from the base of the Witney Coal Formation to the base of the Windrush Formation but is only a persistent member of the assemblages in the seams of the Burford Coal Formation where it may account for $1 \%$ of the assemblage. In general, however, it represents no more than $0.2 \%$ of the assemblage.

Vestispora witneyensis first appears as a rare and sporadic component of the assemblages in seams of the 


\begin{tabular}{|c|c|c|c|c|c|c|c|}
\hline Formation & Seam & $\begin{array}{c}\text { No. of } \mathrm{BHs} \\
\text { with named } \\
\text { seam }\end{array}$ & $\begin{array}{c}\text { No. of BHs } \\
\text { Thymospora } \\
\text { pseudothiessenii }\end{array}$ & $\begin{array}{c}\text { Vestispora } \\
\text { burfordiensis }\end{array}$ & $\begin{array}{l}\text { Schopfites } \\
\text { dimorphus }\end{array}$ & $\begin{array}{l}\text { Vestispora } \\
\text { witneyensis }\end{array}$ & $\begin{array}{l}\text { named seam } \\
\text { Punctatosporites } \\
\text { granifer }\end{array}$ \\
\hline Windrush & Marston/ & & & & & & \\
\hline \multirow[t]{5}{*}{ Keele } & Napton* & 2 & 1 & & & & \\
\hline & Overthorpe & 3 & 2 & & & & \\
\hline & Newington & 6 & 4 & 1 & 1 & & \\
\hline & Lower & & & & & & \\
\hline & Newington & 3 & 2 & 2 & & & \\
\hline \multirow{4}{*}{$\begin{array}{l}\text { Burford } \\
\text { Coal }\end{array}$} & Top or combined & 7 & 7 & 6 & 7 & 5 & \\
\hline & $\begin{array}{l}\text { Top and Low } \\
\text { Broughton }\end{array}$ & & & & & & \\
\hline & $\begin{array}{l}\text { Low Broughton } \\
\text { Seam below }\end{array}$ & 4 & 4 & 3 & 4 & 3 & \\
\hline & Low Broughton & 3 & 1 & 2 & 3 & 2 & \\
\hline Crawley & Un-named seams & 4 & 0 & 3 & 2 & 3 & \\
\hline \multirow[t]{2}{*}{ Witney Coal } & $\begin{array}{l}\text { Upper Milton or } \\
\text { combined } U / L\end{array}$ & Milton $^{9}$ & 4 & 1 & 4 & 5 & 9 \\
\hline & Lower Milton & 5 & 2 & & 1 & 0 & 5 \\
\hline Arenaceous & Eynshamt & 4 & 0 & & & 1 & 2 \\
\hline \multirow{2}{*}{ Coal } & Aston & 5 & 2 & & & 1 & 5 \\
\hline & Apleył & 4 & 1 & & & 0 & 4 \\
\hline
\end{tabular}

* - name used in South Warwickshire prospect

$\dagger-$ includes seams between Aston and Lower Milton

$\ddagger$ - includes seams below Aston

N.B. - The named seam may comprise several beds of coal separated by dirt. The occurrence of a spore in only one bed is sufficient for it to be recorded in the seam.

Table 2. Frequency of occurrence of selected spores in the main coal horizons of the Oxfordshire and S.E. Warwickshire Coalfield.

Arenaceous Coal Formation. It has not been recorded from the Lower Milton seam but it occurs regularly in the Upper Milton seam and in seams up to and including the Top Broughton. Its level of abundance is similar to that of $V$. burfordiensis.

Punctatosporites granifer is present in nearly all samples of the seams in the Arenaceous and Witney Coal Formations. It ranges in abundance from 1-8\% in the majority of samples investigated. The upper limits of the epibole and of the stratigraphic range of this species coincide at the horizon of the Upper Milton Seam.

\section{RANGES OF SELECTED SPORES IN SOME OTHER BRITISH COALFIELDS}

\section{Thymospora pseudothiessenii}

In north Staffordshire thin coals from the Etruria Marl Formation, generally considered to be of Upper Westphalian $\mathrm{C}$ age, were sampled at an exposure and from two boreholes (Smith \& Butterworth, 1967). Spores diagnostic of the T. obscura Zone including Schopfites dimorphus were present at all three localities and $T$. pseudothiessenii at two. It is difficult to reconcile the occurrence of these species in strata of presumed Upper Westphalian $C$ age with the stratigraphic ranges established in Oxfordshire. However, Besley (1983) has shown that the base of the Etruria Marl Formation in north Staffordshire lacks chronostratigraphic significance, the base of the continuous 'red bed' facies being strongly diachronous. There is the possibility that locally the upper strata of the Formation may be of Westphalian D age. On the other hand, the spore evidence from one of the boreholes may be unreliable. Besley has pointed out that the material used for spore analysis was in the form of chippings from an uncased borehole thus allowing the possibility of contamination by spores from the overlying Newcastle Formation of Westphalian $\mathrm{D}$ age.

In Britain, seams of suitable rank are poorly repre- 
sented in that part of the succession which includes the Westphalian C/D boundary. This is due in part to the hiatus of the Symon Unconformity. In the Forest of Dean, $T$. pseudothiessenii was not recorded from either the Trenchard or Coleford High Delf seams near the top of the Trenchard and the bottom of the Pennant Formations respectively. In South Wales, the species was not recorded from the Tillery (Brithdir) and Tillery Rider (Brithdir Rider) seams in the lower part of the Pennant Formation.

In coalfields situated to the north of the WalesBrabant Massif, T. pseudothiessenii is common in certain seams in the Halesowen, or equivalent formations, in strata which may be contemporary with the Burford Coal Formation in Oxfordshire. Unfortunately, the precise lithostratigraphic correlation of these beds is uncertain.

South of the Wales-Brabant Massif, $T$. pseudothiessenii is apparently absent from seams in the Farrington Formation of the Bristol and Somerset Coalfields and from the two seams in the middle of the Pennant Formation of the Forest of Dean. These horizons may therefore be the equivalent of strata from below the Burford Coal Formation in Oxfordshire in which $T$. pseudothiessenii is uncommon. However, this does not explain its absence from the Woor Green seam in the Supra Pennant Formation of the Forest of Dean in which Schopfites dimorphus occurs. No samples have been examined from the crucial parts of the species range in South Wales.

T. pseudothiessenii has been recorded, sometimes as an abundant element of the assemblages, from seams of the Keele Formation, or strata of equivalent age, in all the coalfields subject to palynological investigation in Britain.

Thus, with the exception of north Staffordshire, the range and abundance of $T$. pseudothiessenii in the British coalfields is generally in agreement.

\section{Schopfites dimorphus}

Apart from its apparently anomalous occurrence in seams of the Etruria Marl in north Staffordshire, Schopfites dimorphus has a similar range in all the British coalfields in which it occurs. It is confined to a relatively restricted portion of the Upper Coal Measures, namely to seams in the upper part of the Halesowen Formation and at the base of the overlying Keele Formation. Its absence from the Mynyddislwyn seam and from the Tillery and Tillery Rider seams in South Wales conforms to this pattern. The apparent absence of the species from seams in the Radstock Formation of the Bristol and Somerset coalfields is evidence that these beds are younger than the Burford Coal Formation of Oxfordshire, and may correlate with the Keele Formation elsewhere. However, its presence in the Woor Green seam from the Forest of Dean is interesting in view of the possible Cantabrian age assigned to the highest beds above the Household Coals on the basis of the fossil plants (Cleal in Ramsbottom, 1978).

\section{Punctatosporites granifer}

Small monolete spores with scabrate to granulate ornament were regarded as a single morphographic species by Smith \& Butterworth (1967) and referred to $P$. granifer. In later work in Oxfordshire, Smith (in Poole, 1977, 1978) separated the more finely ornamented forms which he referred to $P$. punctatus. This was supported by the systematic study of monolete spores by Alpern \& Doubinger (1973). There is thus no evidence in Britain relating to the range and abundance of $P$. granifer having the form illustrated in this paper.

\section{Vestispora spp.}

The two new species of Vestispora have only been recorded from seams in the small coalfield at Newent and from the Oxfordshire and southeast Warwickshire basins. It seems unlikely that these spores are confined to these coalfields.

\section{MIOSPORE ZONES IN THE UPPER COAL MEASURES OF OXFORDSHIRE}

In their study of miospore assemblages in British coalfields, Smith \& Butterworth (1967) placed all assemblages containing Thymospora into a single zone, the base of which was roughly equivalent to the Westphalian C/D boundary. In his work on the Oxfordshire Coalfield, Smith, in Poole $(1977,1978)$ laid the foundation for subdivision of this zone. The present work proposes the replacement of Assemblage XI of Smith \& Butterworth (1967) by a tripartite division, which is designated numerically XI-XIII to continue the zones recognised by Smith \& Butterworth (1967). The relationship between the new zones and the stratigraphic ranges of the selected species used for their recognition is shown in Fig. 3.

The lithological horizons and the species associated with these zones are summarised in descending order below:-

Zone XIII - Seams of the Windrush Formation above the Newington Seam. T. pseudothiessenii is characteristic (coarse forms common). Other species listed below are absent.

Zone XII - Seams of the Witney and Burford Coal Formations and the intervening Crawley Formation. The top of the Zone is placed immediately above the Newington Seam at the base of the Windrush Formation. Schopfites dimorphus, Vestispora burfordiensis and $V$. witneyensis all occur as characteristic species. 


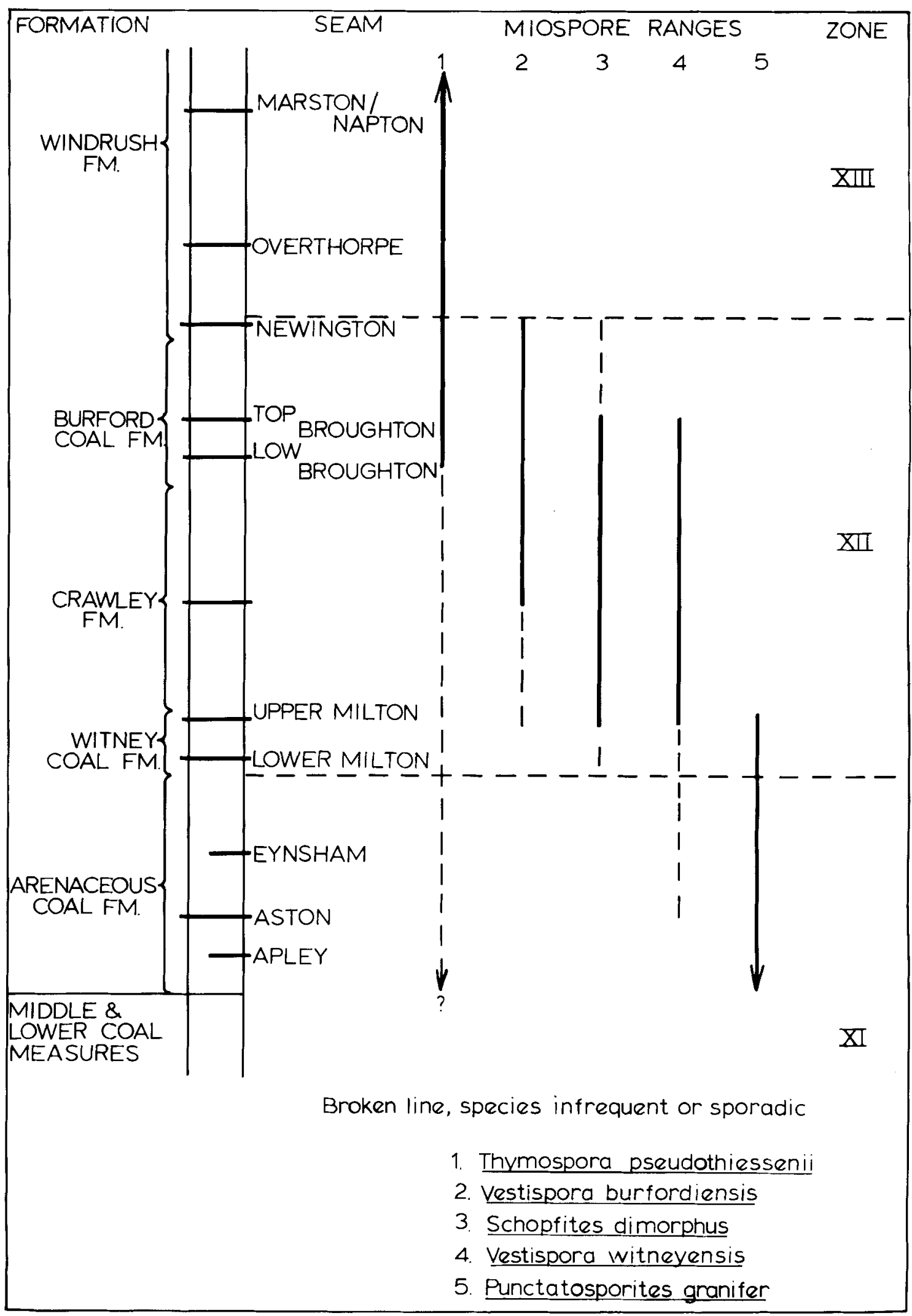

Fig. 3. Zonation of seams in the Upper Coal Measures of the Oxfordshire Coalfield based on the stratigraphic ranges of selected spores. 
The base of the epibole of $T$. pseudothiessenii occurs at the base of the Burford Coal Formation in the upper part of the Zone. $P$. granifer is confined to the coals of the Milton Group.

Zone XI - Seams of the Arenaceous Coal Formation. $P$. granifer usually common. Thymospora represented by $T$. obscura and $T$. pseudothiessenii in small numbers. $V$. witneyensis is scarce.

It is considered premature to designate the zones by spore names before the miospore flora has been thoroughly documented. This will avoid the use of inappropriate names and confusion with the names already introduced by Peppers (1985) for a similar suite of biozones in strata of the Illinois Basin in North America considered to be equivalent in age to the Westphalian D of Europe. A comparison of the two zonal schemes shows some differences.

Peppers designated his three Assemblage Zones M1, $\mathrm{CP}$ and GD in ascending order. The base of his M1 Zone corresponds to the first appearance of Cadiospora magna, Mooreisporites inusitatus and the sporadic appearance of $T$. pseudothiessenii. These spores were recorded from the lowest seams from certain of the boreholes in the Oxfordshire Basin but because the lower part of the Upper Coal Measures is not present in the basin, the horizon at which these species first appear is not known. The lower and upper limits of Peppers' CP Zone and the limits of Assemblage Zone XII of the present work correspond to the first and last appearance of Schopfites colchesterensis and $S$. dimorphus. However, in Illinois the lower limit of the CP Zone is coincident with the base of the $T$. pseudothiessenii epibole, whereas in Oxfordshire the base of the epibole occurs in the upper part of Zone XII. In Illinois $T$. pseudothiessenii declines in abundance in seams above the range of $S$. colchesterensis whereas in Oxfordshire no such decline is apparent. The reduction in the numbers of $T$. pseudothiessenii is characteristic of the assemblages in Peppers' GD Zone, the uppermost of the three zones under discussion. The two species which designate this zone are Lycospora granulata and Cappasporites distortus. It is difficult to compare the range and abundance of $L$. granulata (Kosanke) since in this work the species has been included along with other Lycospores having a narrow flange and cingulum under the collective name $L$. pusilla. $C$. distortus (Urban) may be conspecific with Apiculatisporites irregularis (Alpern) Smith \& Butterworth. The latter species is present throughout the Oxfordshire sequence but varies in abundance both within and between seams. It is unlikely that the features which mark the top of Peppers' GD Zone will be observed in Oxfordshire where strata of the appropriate age are probably lacking.

\section{BIOSTRATIGRAPHY}

Miospore assemblages from seams at the base of the Upper Coal Measures in Oxfordshire are characterised by species such as $T$. obscura, Cadiospora magna and Mooreisporites inusitatus which are diagnostic of the $T$. obscura Assemblage Zone XI of Smith \& Butterworth (1967) and the lower part of the T. obscura-T. thiessenii (OT) Zone of Clayton et al. (1977). The base of the $T$. obscura Zone is determined by the first appearance of the monolete verrucate spores of the genus Thymospora. This genus is widely known from Carboniferous strata in Canada (Hacquebard, 1961), North America, Europe and Russia (Butterworth \& Smith, 1976) and is obviously an important horizon for correlation (Laveine, 1976).

It has long been known that there is an approximate coincidence between the appearance of Thymospora and the Westphalian C/D boundary. However, attempts to use spores to define this boundary have been hindered partly by the lack of agreement concerning the palaeontological criteria used to define the boundary and partly from the lack of faunal and floral controls on the sections examined for spores. However, some progress has been made to resolve the problem. Since fossil plants provide a more useful basis for the biostratigraphic subdivision of the uppermost division of the Westphalian stage than the mussels, it is appropriate to examine the first appearance of Thymospora in relation to the record of the leaves of fossil plants. Laveine (1976) has shown that in those basins of N.W. Europe from which he examined the fossil floras, Thymospora, Linopteris obliqua var bunburii and Neuropteris ovata appear in sequence over a very short stratigraphic interval. Recently Cleal (1984) has compared the plant distribution in the Saar with that in the Pennant Formation of South Wales and has proposed a tripartite division of the Westphalian $\mathrm{D}$. He equates the base of the Westphalian D with the appearance of $L$. obliqua var bunburii which in South Wales occurs near the top of the Rhondda Beds. This horizon is lower than that shown by Ramsbottom et al. (1978) who placed the base of the Westphalian D at the Hughes seam which marks the arbitrary boundary between the Phillipsii and Tenuis Chronozones and the base of Cleal's middle zone.

In South Wales only two seams have been examined from the appropriate horizon, namely the Tillery (Brithdir) and Tillery Rider (Brithdir Rider). According to the boundary established by Cleal, these seams are just above the base of the Westphalian D stage. Thymospora obscura was present in the assemblage from the Tillery Rider. Thus, on the basis of this admittedly somewhat slender evidence, Thymospora in South Wales only occurs in seams of Westphalian D age. 
Unfortunately, Cleal has not established the base of Westphalian D in other coalfields from which Thymospora has been recorded and correlations in these coalfields are based on other evidence. It is worth detailing the stratigraphical evidence in order to highlight the problem of correlating the first occurrence of Thymospora with the Westphalian stage boundaries in Britain. Only coalfields with seams at the appropriate horizons are considered.

In Oxfordshire, T. obscura has been found in the lowest seams of the Arenaceous Coal Formation whose stratigraphy, excluding the evidence of the spores, is based on lithological considerations.

In the Forest of Dean, T. obscura has been recorded from the Trenchard Seam which is believed to be of late Westphalian $\mathrm{C}$ age (Phillipsii chronozone) though fossil evidence is lacking (Ramsbottom et al., 1978). In the Bristol and Somerset coalfields three seams from the Farrington Formation have been examined and all contained $T$. obscura. This formation contains typical Westphalian D floras (Ramsbottom et al., 1978). No seams from the underlying Mangotsfield Formation of Westphalian C, or possibly of lowest D, age (Ramsbottom et al., 1978) have been examined.

There remains the anomalous spore associations previously mentioned from the thin coals at the base of the Etruria Marl facies in north Staffordshire. These red beds occur between the grey measures of the Blackband Formation containing faunas of the Phillipsii chronozone and the overlying Newcastle Formation belonging to the Tenuis chronozone (Ramsbottom et al., 1978).

If the stratigraphically lower base of the Westphalian $D$ proposed by Cleal is accepted, then there is at present no unequivocal evidence for the occurrence of Thymospora $\mathrm{spp}$ in strata of Westphalian $\mathrm{C}$ age in Britain.

The base of the Thymospora epibole is a widely reported event of biostratigraphic significance occurring in mid Westphalian D times. In Oxfordshire it can be recognised in seams at the base of the Burford Coal Formation and in other British coalfields in seams which may correlate with this horizon in Oxfordshire. According to Laveine (1976) using the data of Alpern (1969) the base of the Thymospora epibole equates with the horizon of Tonstein 60 in Lorraine. Using the macrofloral ranges given by Donsimoni (1981), Cleal (1984) considers Tonstein 60 corresponds to the base of his Lobatopteris micromiltoni Zone (middle zone of three into which the Westphalian $D$ is subdivided) which he equates with the base of the Hughes Beds in South Wales. Laveine (1976), on the other hand, had earlier equated Tonstein 60 with the Five Feet seam in the Swansea Beds which overlie the Hughes Beds. It is worth noting that Cleal broadly equates his $L$. micromiltoni Zone with the lower part of Dix's Floral Zone I, whereas the Hughes Beds were placed in the older floral zone $\mathrm{H}$ by Dix (1934). In the present state of knowledge, it would be unwise to equate the base of the Burford Coal Formation in Oxfordshire with either the base of the L. micromiltoni Zone or with the Hughes Seam in South Wales.

In North America, Peppers (1985) comparing the ranges of miospores in the Pennsylvanian of Illinois with those in Western Europe, recognises an epibole in the numbers of $T$. pseudothiessenii whose base lies near the upper limit of the Spoon Formation (Desmoinesian Series).

Other species whose ranges in the Lower and Middle Westphalian D of Oxfordshire makes them locally useful for correlation purposes, and which may have a wider biostratigraphical significance, are Schopfites spp. and Punctatosporites granifer.

In northern France, Loboziak (1971) showed $S$. colchesterensis appearing somewhat later in the succession than $T$. obscura. However, according to Peppers (1985) the spore identified and illustrated by Loboziak (1971, pl. 4, fig. 25) as $S$. colchesterensis is closer to his Schopfites sp., which in Illinois appears at the same time as Thymospora. This form is less coarsely ornamented than $S$. colchesterensis and has not been recognised in Oxfordshire. In Illinois, Peppers (loc. cit.) shows that the ranges of $S$. dimorphus and $S$. colchesterensis (Smith \& Butterworth, 1967 do not distinguish between these species) are confined to parts of the Spoon and Carbondale Formations and terminate well before the disappearance of $T$. pseudothiessenii. He equates these ranges with strata of mid Westphalian D age in Europe. Peppers cites the range in Britain, on the authority of Smith \& Butterworth (1967), as in coals throughout the Westphalian D and in the Etruria Marl. However, the range now established in Oxfordshire shows much closer agreement with the range span in Illinois although in North America $S$. colchesterensis first appears at the base of the $T$. pseudothiessenii epibole, whereas in Oxfordshire $S$. dimorphus occurs somewhat earlier.

The abundance of $P$. granifer in seams of uppermost Westphalian $\mathrm{C}$ and Westphalian $\mathrm{D}$ age in boreholes outside the mining district of Limburg in the Netherlands led Van Wijhe \& Bless (1974) to name their youngest miospore zone after this species. Unfortunately, due to the presence of a red bed sequence in the upper part of the succession in these Dutch boreholes, resulting in the elimination of the spores, no comparision is possible with the younger strata in Oxfordshire.

The range in Northern France (Loboziak, 1971) and in the Saar-Lorraine coalfields (Alpern et al., 1969) is given as Westphalian B-D; in the Campine basin of Belgium (Somers, 1971) as Westphalian C-D and in the Ruhr coalfield (Grebe, 1972) as Westphalian C although it is rare in the lower part. However, the 
possible confusion between morphologically similar forms (Van Wijhe \& Bless, 1974) combined with the limited development of seams in the basal Westphalian $\mathrm{D}$ in certain of these coalfields makes comparison difficult. Similarly, Peppers (1979), in his comparative studies, considers $P$. granifer to be a synonym of Laevigatosporites punctatus. There is thus no unequivocal evidence from N.W. Europe or from North America to corroborate the range in Oxfordshire where it is restricted to the presumed lower Westphalian D strata.

The Westphalian-Stephanian boundary has been traditionally placed at the unconformity at the base of the Holz Conglomerate. According to Cleal (1984) the fossil plants provide no unequivocal evidence of Cantabrian (basal stage of Stephanian) from strata below the Holz Conglomerate in the Saar-Lorranie Basins.

Above the Holz Conglomerate in these basins and at similar horizons in the Decize Basin and the basins of the Central Massif, significant changes take place in the miospore assemblages with an increase in the abundance of such species as Spinosporites spinosus and Polymorphisporites spp., and the appearance of Potonieisporites novicus and Aumancisporites striatus accompanied by a reduction in the numbers of Thymospora spp. and the disappearance of Lycospora spp.

The disappearance of Lycospora spp., Thymospora pseudothiessenii and Cappasporites distortus (possibly conspecific with Apiculatisporis irregularis (Alpern, Smith \& Butterworth) has been recorded in part by Kosanke (1950) and by Peppers $(1964,1970)$ in Illinois within the lower part of the Modesto Formation at the boundary of the Desmoinesian and Missourian Series. This event has been used by Peppers (1985) to define the boundary between his $L$. granulata $C$. distortus (GD) and $P$. minutus $P$. obliquus (MO) Zones which he equates with the Westphalian D/Stephanian boundary in Europe. It should, however, be noted that Lycospora spp. have been recorded from younger strata of the Appalachian area (Clendening, 1974). According to Clayton et al. (1977) in Western Europe Lycospora spp. remain abundant throughout the Stephanian until the Autunian.

In Oxfordshire both Lycospora spp. and A. irregularis are well represented in the younger seams and there is no evidence of miospore assemblages of postWestphalian character.

It is hoped that the recognition of the proposed miospore assemblage zones may assist the intercoalfield correlation of strata of Upper Coal Measures age in Britain. It may prove more difficult to relate the miospore zone boundaries to horizons established from macroplant remains since the classic collections of the latter from the South Wales Coalfield are from areas where the rank of the coals of the appropriate age is too high to obtain recognisable miospores.

\section{ACKNOWLEDGEMENTS}

The author wishes to thank the National Coal Board for the opportunity to carry out this work and for permission to publish the results. Special thanks are due to Ron Goossens, Chief Geologist of the N.C.B., and to the two members of his staff, Phil Eaton and Eddie McIneirnie, with special responsibilities for the Oxfordshire and South Warwickshire Prospects, for helpful information on seam correlation and nomenclature. The author is also indebted to Pamela Spriggs for practical help and for information based on her own observations.

\section{Manuscript received February 1986}

Revised manuscript accepted June 1986

\section{REFERENCES}

Alpern, B., Choffe, M., Lachkar, G. \& Liabeuf, J. J. 1969. Synthése des zonations palynolgiques des Bassins Houillers de Lorraine et de Sarre. Rev. Micropaléont., 11 (4), 217-221.

Alpern, B. \& Doubinger, J. 1973. Les miospores monolètes du Paléozoique. C.I.M.P. - Microfossils organiques du Paléozoique, No. 6. Editions du Centre National de la Recherche Scientifique, Paris, 103 pp.

Alpern, B., Liabeuf, J. J. \& Navale, G. K. B. 1964. Beziehungen zwichen palynologischen und petrographischen Zonenfolgen in der Steinkohlenflozen. Fortschr. Geol. Rheinl. Westfal., 12, 303-316.

Besley, B. M. 1983. The Sedimentology and Stratigraphy of Red Beds in the Westphalian $A$ to $C$ of Central England. Unpub. Ph.D. Thesis, University of Keele.

Butterworth, M. A. \& Smith, A. H. V. 1976. The age of the British Upper Coal Measures with reference to their miospore content. Rev. Palaeobot. and Palynol., 22, 281-306.

Clayton, G., Coquel, R., Doubinger, J., Gueinn, K. J., Loboziak, S., Owens, B. \& Streel, M. 1977. Carboniferous Miospores of Western Europe: illustration and zonation. Meded. Rijks geol. Dienst, 29, $71 \mathrm{pp}$.

Cleal, C. J. 1984. The Westphalian D floral biostratigraphy of Saarland (Fed. Rep. Germany) and a comparison with that of South Wales. Geol. J., 19, 327-351.

Clendening, J. A. 1974. Palynological evidence for a Pennsylvanian age assignment of the Dunkard Group in the Appalachian Basin, Part II. Coal Geol. Bull., No. 3, W. Va Geol. Econ. Surv. 107 pp.

Dix, E. 1934. The Sequence of Floras in the Upper Carboniferous, with special reference to South Wales. Trans. R. Soc. Edinb., 57, 789-838.

Donsimoni, M. 1981. Le bassin houiller lorrain: synthèse géologique. Mém. Bur. Rech. géol min., 117, 99 pp.

Dunham, K. C. \& Poole, E. G. 1974. The Oxfordshire Coalfield. J. geol. Soc. (London) 130, 387-391.

Grebe, H. 1972. Die Verbreitung der Mikrosporen in Ruhr Karbon von den Bochumer Schichten bis zu den Dorstener Schichten (Westfal A-C). Palaeontographica, 140B, 27115.

Hacquebard, P. A. 1961. Palynological studies of some Upper and Lower Carboniferous strata in Nova Scotia. 3rd Conf. Origin and Const. Coal, Nova Scotia (1956), 227-256. 
Harvey, R. D. \& Dillon, J. W. 1985. Maceral distributions in Illinois coals and their paleoenvironmental implications. In Phillips, T. L. and Cecil, C. B. (Eds), Paleoclimatic Controls on Coal Resources of the Pennsylvanian System of North America. Int. J. Coal Geol., 5, 230 pp.

International Committee for Coal Petrology (ICCP). 1963. International Handbook of Coal Petrography. Second Edition, CNRS, Paris, 1971. Supplement to 2nd Edition. 1976. 2nd Supplement to 2nd Edition.

Jones, J. M., Davis, A., Cook, A. C., Murchison, D. G. \& Scott, E. 1984. Provincialism and correlations between some properties of vitrinites. Int. J. Coal Geol, , 3, 315-331.

Kosanke, R. M. 1950. Pennsylvanian spores of Illinois and their use in correlation. Ill. State. Geol. Surv. Bull., 74, 128 pp.

Laveine, J. P. 1976. Report on the Westphalian D. Proc. Field Gen. Meeting, I.U.G.S. Sub-comm. Carbonif. Strat., Prague (1973), 71-87.

Loboziak, S. 1971. Les micro- et mégaspores de la partie occidentale du bassin houiller du Nord de la France. Palaeontographica, 132B, 127 pp.

Navale, G. K. B. 1964. Palynological studies of Merlebach coals in conjunction with petrographic structure. Palaeobotanist, 12, 232-249.

Peppers, R. A. 1964. Spores in strata of the Late Pennsylvanian cyclothems in the Illinois Basin. Ill. State Geol. Surv. Bull., 90, 89 pp.

Peppers, R. A. 1970. Correlation and palynology of coals in the Carbondale and Spoon formations (Pennsylvanian) of the north eastern part of the Illinois Basin. Ill. State Geol. Surv. Bull., 93, 173 pp.

Peppers, R. A. 1985. Comparison of Miospore Assemblages in the Pennsylvanian System of the Illinois Basin with those in the Upper Carboniferous of Western Europe. C.R. Cong. Strat. Géol. carbon., Champaign-Urbana (1979), 2, 483-502.

Phillips, T. L. \& Peppers, R. A. 1984. Changing patterns of Pennsylvanian coal-swamp vegetation and implications of climatic control on coal occurrence. Int. J. Coal Geol., 3, 205-255
Phillips, T. L., Peppers, R. A., Avcin, M. J. \& Laughnan, P. F. 1974. Fossil Plants and Coal: Patterns of change in Pennsylvanian coal swamps of the Illinois Basin. Science, 184, 1367-1369.

Poole, E. G. 1969. The Stratigraphy of the Geological Survey Apley Barn Borehole, Witney, Oxfordshire. Bull geol. Surv. G.B. . No. 29, 104 pp.

Poole, E. G. 1977. Stratigraphy of the Steeple Aston Borehole, Oxfordshire. Bull. geol. Surv. G.B., No. 57, 85 pp.

Poole, E. G. 1978. Stratigraphy of the Withycombe Farm Borehole, near Banbury, Oxfordshire. Bull. geol. Surv. G.B., No. 68, $63 \mathrm{pp}$.

Ramsbottom, W. H. C., Calven, M. A., Eagen, R. M. C., Hodson, F., Holiday, D. W., Stubblefield, C. J. and Wilson, R. B. 1978. A Correlation of Silesian Rocks in the British Isles. Geol. Soc. Lond. Special Report No. 10, 82 pp.

Smith, A. H. V. 1962. The Palaeoecology of Carboniferous Peats based on the Miospores and Petrography of Bituminous Coals. Proc. Yorks. geol. Soc., 33, +23-474.

Smith, A. H. V. 1964. Zur Petrologie und Palynologie der Kohlenfloze des Karbons und ihrer Begleitschichten. Fortschr. Geol. Rheinl. Westfal., 12, 285-3(1) 2.

Smith, A. H. V. \& Butterworth, M. A. 1967. Miospores in the coal seams of the Carboniferous of Great Britain. Spec. Pap. Palaeontol., No. 1, 324 pp.

Somers, Y. 1971. Etude palynologique du Westphalian du Bassin de Campine et Révision du gentre Lycospora. Ph.D. Thesis. Univ. Liège. $214 \mathrm{pp}$.

Styan, W. B. \& Bustin, R. M. 1983a. Petrography of some Fraser River Delta peat deposits: coal maceral and microlithotype precursors in temperate-climate peats. Int. J. Coal. Geol., 2, 321-370.

Styan, W. B. \& Bustin. R. M. 1983b. Sedimentology of Fraser River Delta peat deposits: a modern analogue for some deltaic coals. Int. J. Coal. Geol., 3, 101-143.

Van Wijhe, D. H. \& Bless, M. J. H. 1974. The Westphalian of the Netherlands, with special reference to miospore assemblages, Geol. en Mijnb., 53, 295-328. 